\title{
In vitro Shoot Multiplication of Bupleurum disticho- phyllum Wight - A Native Medicinal Plant of Southern India
}

\author{
S. Karuppusamy and T. Pullaiah \\ Department of Botany, Sri Krishnadevaraya University, Anantapur-515 003, India. \\ Email:ksamylin@yahoo.co.in/pullaiaht@yahoo.co.in \\ Key words: Bupleurum distichophyllum, Medicinal plant, Micropropagation, \\ Conservation
}

\begin{abstract}
Shoot multiplication of Bupleurum distichophyllum was achieved from the nodal and shoot tip explants of mature plants using MS with different concentrations and combinations of growth regulators. Maximum explant response was from axillary shoots and the highest number of shoots per explant was obtained on MS fortified with $1.0 \mathrm{mg} / 1 \mathrm{BAP}$. The highest degree of axillary shoot proliferation was found to be 74 and $70 \%$ for nodal- and shoot tip explants, respectively on the medium containing $1.0 \mathrm{mg} / 1 \mathrm{BAP}+0.1 \mathrm{mg} / 1 \mathrm{NAA}$. The combination of BAP and $\mathrm{GA}_{3}$ was also found to be effective for both type of explants. The degree of shoot formation was affected by explant types and the exogenous hormonal regime in the medium. The regenerated shoots were successfully rooted on MS supplemented with $2.0 \mathrm{mg} / 1 \mathrm{IBA}$, after sequential hardening, survival rate was $71 \%$.
\end{abstract}

\section{Introduction}

Bupleurum (Apiaceae) is commonly known as Hare's Ear. Bupleurum root is one of the most important herbs used in Chinese herbalism. The part of the plant used medicinally is the root, which is dug up in spring or autumn, dried in the sun, and then cut into short pieces. Bupleurum is not a tonic herb, but is useful in the tonic system because of its ability to relieve liver tension and digestive disturbances, and because its actions are detoxifying and anti-microbial. An essential oil in Bupleurum is responsible for its ability to relieve surface heat. This herb is anti-inflammatory, hepato-protective, mild sedative, antipyretic, analgesic, adaptogen, and anti-tussive (Yamamoto et al. 1975, Utrilla et al. 1991). The primary chemical constituents of Bupleurum root are: fatty acids, glycosides, oleic acid, palmitic acid, quercetin, and narcissin (Park et al. 2002). This herb also contains constituents known as saikosaponins that appear to account for much of its medicinal activity (Oka et al. 1995). Bupleurum root is a primary component in 
dozens of classical formulations which serve a wide variety of harmonizing activities, all of which regulate body energy, help relieve blockages in the body, and discharges the toxins safely out of the system (Packer and Kliger 1984). It can be used for treating the common cold that is accompanied by alternating symptoms of chills and fever, chest pain, prolapse of the anus, uterus, and other internal organs, and irregular menstruation (Motoo and Sawabu 1994). Regarding its effective liver cleansing capabilities, one of its most important activities is to continually eliminate impurities and waste matter from the system (Hiramtsu et al. 1986). Many of the Indian Bupleurum species are also collected largely for its pharmaceutical importance including Bupleurum distichophyllum. Due to over exploitation this high valued species is threatened with extinction. The present study describes the maximization of shoot multiplication through in vitro micropropagation of Bupleurum distichophyllum by using standard culture medium fortified with different growth regulators.

Micropropagation using axillary shoot proliferation from nodal and shoot tip culture is the most desirable and safe as micropropagules to minimize genetic variation, which can be the source for less variable pharmaceutical preparations. The formation of healthy shoots and its higher rates of multiplication is one of the prerequisites of an economically viable micropropagation protocol. Therefore, the present study was undertaken to determine the effect of different growth regulators on shoot formation and multiplication of genetically stable multiple shoots from the shoot tip and nodal explants of Bupleurum distichophyllum.

\section{Materials and Methods}

Healthy plants of Bupleurum distichophyllum were collected from Palni hills of Western Ghats, Tamilnadu. They were authenticated at Madras Herbarium, Botanical Survey of India, Southern Circle, Coimbatore. Live specimens were planted in the Botanical Garden, Sri Krishnadevaraya University, Anantapur in green house conditions. Nodal segments and shoot tips of $B$. distichophyllum were collected from three months old greenhouse grown plants. These nodal segments and shoot tips were washed under running tap water followed by treatment with a surfactant, Tween $20(5 \% \mathrm{v} / \mathrm{v})$ for $5 \mathrm{~min}$. After repeated washes in double distilled water, surface sterilization was done with mercuric chloride $(0.1 \% \mathrm{w} / \mathrm{v})$ solution for 7-10 min. The sterilized segments were then washed thoroughly with double distilled water and cut into an appropriate size $(1 \mathrm{~cm})$, and cultured on the sterile nutrient medium. The basal medium for shoot induction contained MS salts, vitamins and $30 \mathrm{~g} / 1$ sucrose solidified with $0.8 \% \mathrm{w} / \mathrm{v}$ agar. The $\mathrm{pH}$ of the medium was adjusted to 5.8 before autoclaving at a pressure of $1.06 \mathrm{~kg} \mathrm{~cm}^{2}$. All the cultures were incubated at $25 \pm 2^{0} \mathrm{C}$ with $16 / 8 \mathrm{~h}$ photoperiod under white 
fluorescent tubes $\left(25 \mu \mathrm{mol} \mathrm{m} \mathrm{m}^{-2} \mathrm{~s}^{-1}\right)$. Various plant growth regulators viz., BAP (0.1 - $10 \mathrm{mg} / \mathrm{l})$, IAA (0.1 - $1.0 \mathrm{mg} / \mathrm{l})$, IBA (0.1 - $1.0 \mathrm{mg} / \mathrm{l}), \mathrm{Kn}(0.1-1.0 \mathrm{mg} / \mathrm{l})$ and NAA $(0.1-1.0 \mathrm{mg} / \mathrm{l})$ were tried individually or in combination to obtain the most suitable combination for the proliferation of shoots in established explants. For studying the effect of BAP with $\mathrm{GA}_{3}$, nodal and shoot tip explants from in vitro grown shoots were taken and cultured on MS supplemented with various concentrations and combinations of BAP (viz., 0.5, 1.0, 2.0, $5.0 \mathrm{mg} / \mathrm{l}$ ) and $\mathrm{GA}_{3}$ (viz., $0.1,0.2,0.5,1.0 \mathrm{mg} / \mathrm{l}$ ). Observations were recorded after an interval of four weeks. For root induction, in vitro microshoots with six fully expanded leaves were excised and transferred to half strength MS semisolid medium supplemented with IBA $(2.0 \mathrm{mg} / \mathrm{l})$. Roots were initiated after the fifth day of inoculation in the medium containing $2.0 \mathrm{mg} / 1 \mathrm{IBA}$ and fully profuse roots developed after three weeks. Rooted micro-shoots were thoroughly washed to remove the adhering gel and planted in $5 \mathrm{~cm}$ plastic cups containing a mixture of peat moss and organic manure $(1: 1)$. Plastic cups were covered with polythene bags to maintain humidity. Plants were kept in culture room for ten days. Half strength MS macro salts was poured to the plastic cups at five-days regular interval until the new leaves developed. After the plants were transferred to pots containing organic manure, garden soil and forest humus $(1: 1: 1)$. The pots were watered at two-days interval and were maintained in greenhouse. The survival rate was recorded one month after transfer to pots. All experiments were repeated atleast three times with 15 replicates for each treatment. Data were analyzed by one-way ANOVA and means were compared by Tukey test at $5 \%$ level.

\section{Results and discussion}

Among different concentrations used best response towards shoot proliferation from nodal and shoot tip explants was obtained on MS medium with $1.0 \mathrm{mg} / 1$ BAP (Table 1). For nodal explant, initiation of axillary bud sprouting started from the third day of inoculation (Fig.1a). The highest degree of axillary shoot proliferation was found on medium containing $1.0 \mathrm{mg} / 1 \mathrm{BAP}$ and $95 \%$ of the explants proliferated with $5.3 \pm 0.2$ shoots (Fig. 1b). On the other hand, for shoot tip explants the highest degree of axillary shoot proliferation was found on medium containing $1.0 \mathrm{mg} / 1 \mathrm{BAP}$ and $91 \%$ of the explants proliferated with 4.2 \pm 0.3 shoots. When concentration of BAP increased from 1.0 to $5.0 \mathrm{mg} / 1$ and 10.0 $\mathrm{mg} / \mathrm{l}$ then the percentage of explant response decreased to 72 and $64 \%$. Number of shoots per culture, number of nodes per shoot and shoot length were also found to decrease considerably on media containing 5.0 and $10.0 \mathrm{mg} / 1 \mathrm{BAP}$. The cultured explants did not produce considerable number of shoots per explant and growth of shoots was not satisfactory on the Kn augmented medium. For 

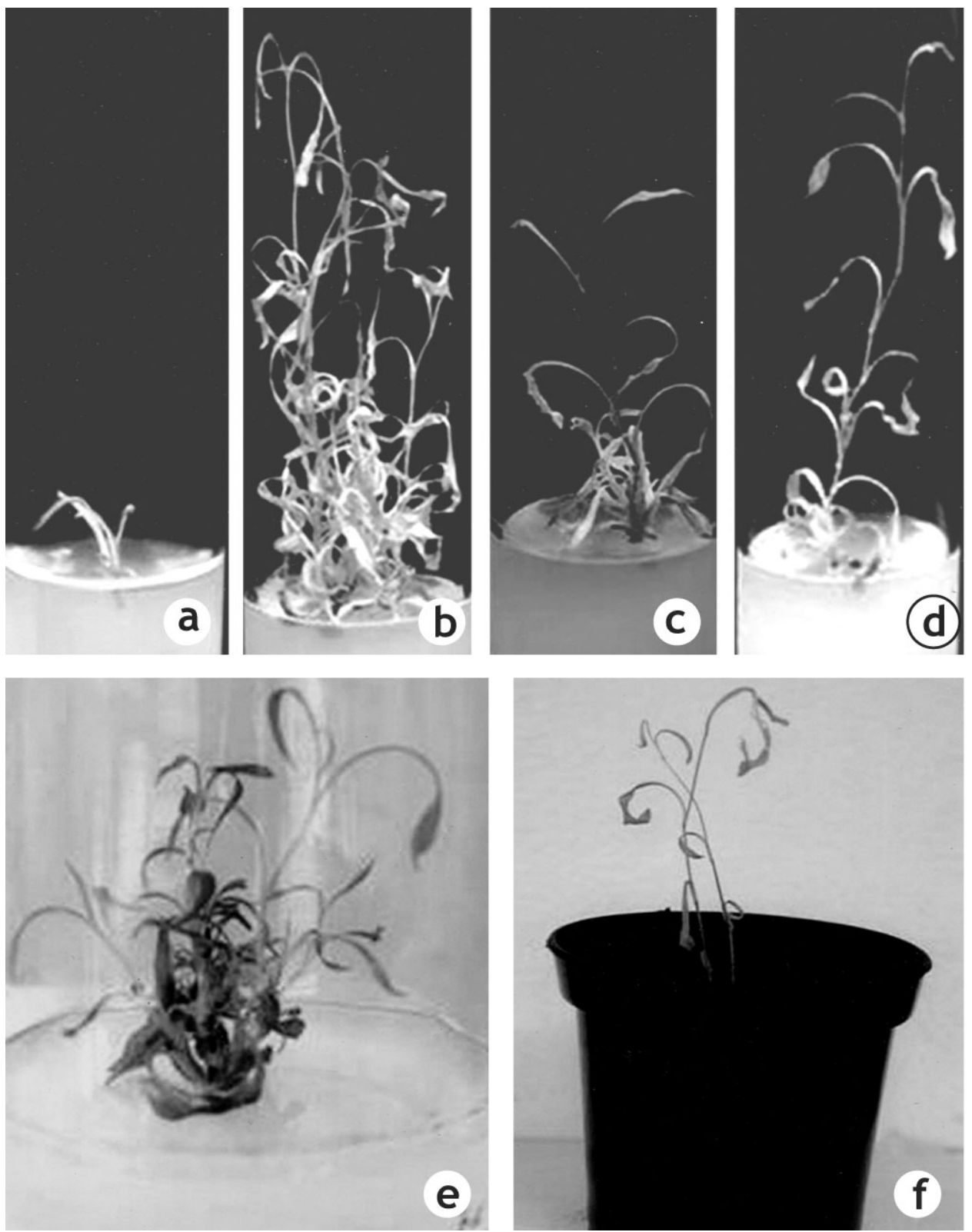

Fig. 1. In vitro shoot multiplication and acclimation of Bupleurum distichophyllum. a. Axillary bud initiation of nodal explants in $1.0 \mathrm{mg} / \mathrm{l}$ BAP. b. Multiple shoot proliferation of nodal explants in $1.0 \mathrm{mg} / 1$ BAP. c. Multiple shoots of nodal explants cultured in $1.0 \mathrm{mg} / 1 \mathrm{Kn}$. d. Shoot tip explants cultured in $1.0 \mathrm{mg} / 1 \mathrm{BAP}+0.1 \mathrm{mg} / 1 \mathrm{GA}_{3}$. e. Nodal explants cultured in $1.0 \mathrm{mg} / 1+0.1 \mathrm{mg} / 1 \mathrm{NAA}$. f. In vitro raised acclimated plantlets after two weeks.

nodal explant, the highest degree of axillary shoot proliferation was found on medium containing $1.0 \mathrm{mg} / 1 \mathrm{Kn}$ and $66 \%$ of the explants proliferated with $2.8 \pm$ 
0.5 shoots (Fig. 1c). On the other hand, for shoot tip explants the highest degree of shoot proliferation was found on medium containing $1.0 \mathrm{mg} / 1 \mathrm{Kn}$ and $66 \%$ of the explants proliferated with $2.8 \pm 0.5$ shoots. The effectiveness of BAP proved to be superior to that of $\mathrm{Kn}$ in regeneration of shoots from both the explants. Similar reports were reported for Bupleurum falcatum, a native of Taiwan (Nalawade et al. 2003).

In the preliminary experiment different concentrations of BAP in combination with different auxins were tested for shoot proliferation. Among different combinations, BAP + NAA showed better proliferation results than other combinations viz. BAP + IBA and BAP + IAA. In the latter combination, $\mathrm{BAP}+\mathrm{IBA}$ and $\mathrm{BAP}+\mathrm{IAA}$, the cultured explants produced fast growing callus that hindered the shoot proliferation rate (data not shown). For this reason, only $\mathrm{BAP}+\mathrm{NAA}$ combination was used in the present investigation to determine the proper ratio between cytokinin and auxin for promoting proliferation of shoots from nodal- and shoot tip explants of Bupleurum distichophyllum. Here both the type of explants were cultured on MS supplemented with $0.5,1.0$ and $5.0 \mathrm{mg} / 1$ BAP in combination with NAA $(0.1,0.2,0.5$ and $1.0 \mathrm{mg} / \mathrm{l})$. Among $16 \mathrm{BAP}+$ NAA combinations used in this experiment the cultured explants produced shoots with roots in 11 combinations. The other five BAP + NAA combinations failed to regenerate shoots but produced only callus. The best result on shoot proliferation was obtained in both nodal and shoot tip explants, when the medium contained $1.0 \mathrm{mg} / \mathrm{l} \mathrm{BAP}$ and a lower concentration of NAA. The highest degree of axillary shoots proliferation was found to be 74 and $70 \%$ in the medium containing $1.0 \mathrm{mg} / 1 \mathrm{BAP}+0.1 \mathrm{mg} / 1 \mathrm{NAA}$ (Table 2; Fig. 1e). The maximum number of shoots per culture and highest length of shoots were $4.0 \pm$ $0.3,5.6 \pm 0.5$ and $3.9 \pm 0.1,4.5 \pm 1.6 \mathrm{~cm}$, respectively. BAP combined with NAA has been reported the best shoot proliferating combination in other Apiaceae members such as Heracleum candicans (Wakhlu and Sharma 1999), Centella asiatica (Shashikala et al. 2005) and Vanasushava pedata (Karuppusamy et al. 2006). In contrast, Fraternale et al. (2002) reported that high concentration of IAA with BAP in MS was suitable for shoot multiplication of Bupleurum fruticosum. It was found that the responses of nodal segment- and shoot tip explants for shoot multiplication was not the same. Among explants the nodal segments were found to be the best for shoot multiplication in comparison to the shoot tip explant. This differential response with regard to morphogenic development from Bupleurum distichophyllum explants may be due to the genotype differences of the Bupleurum material used in the present investigation with those reported earlier (Fraternale et al. 2002; Uei-Chern et al. 2006). This effect can be attributed to the presence of axillary buds at more advanced stages and absence of apical dominance in the nodal explants. Nodal and shoot tip explants from in vitro 


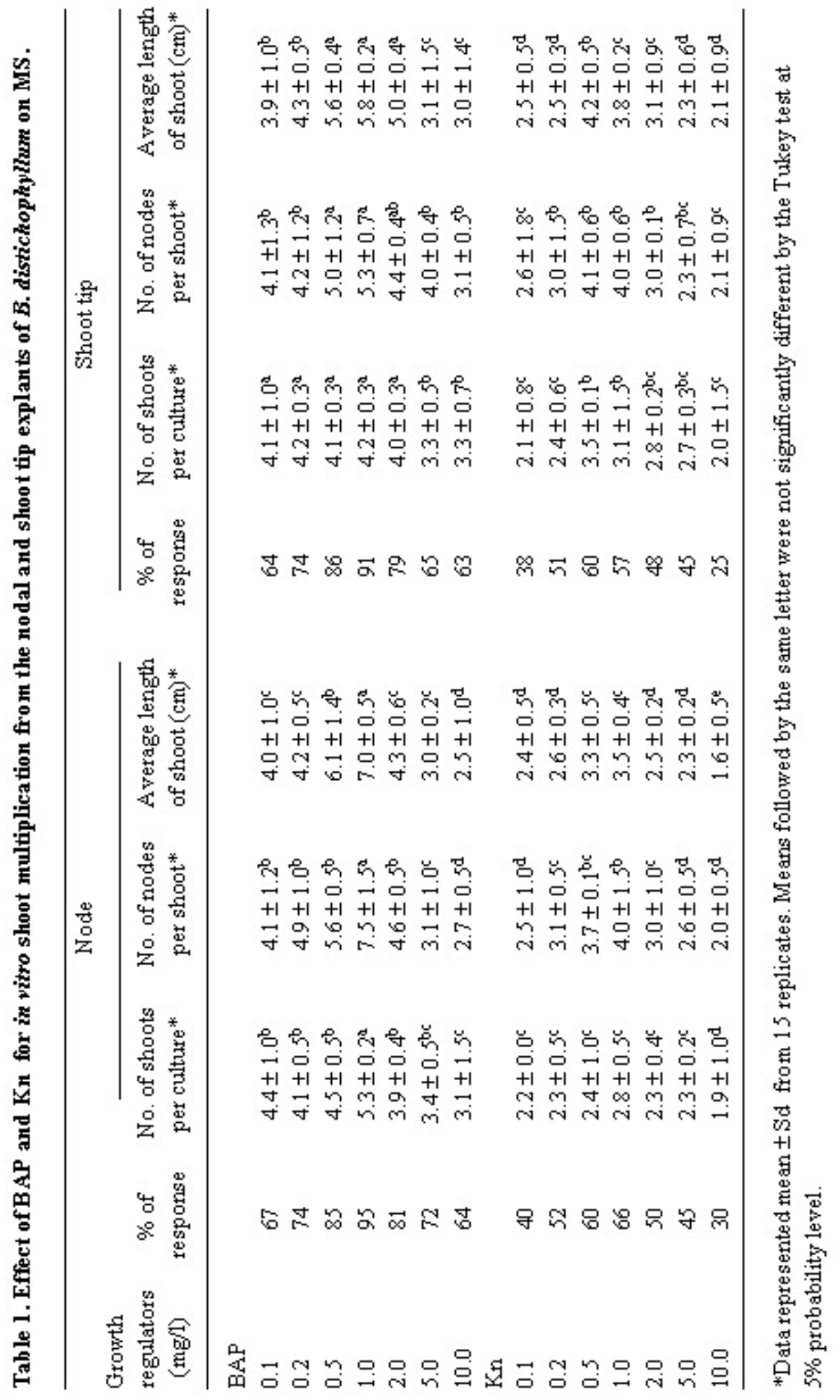




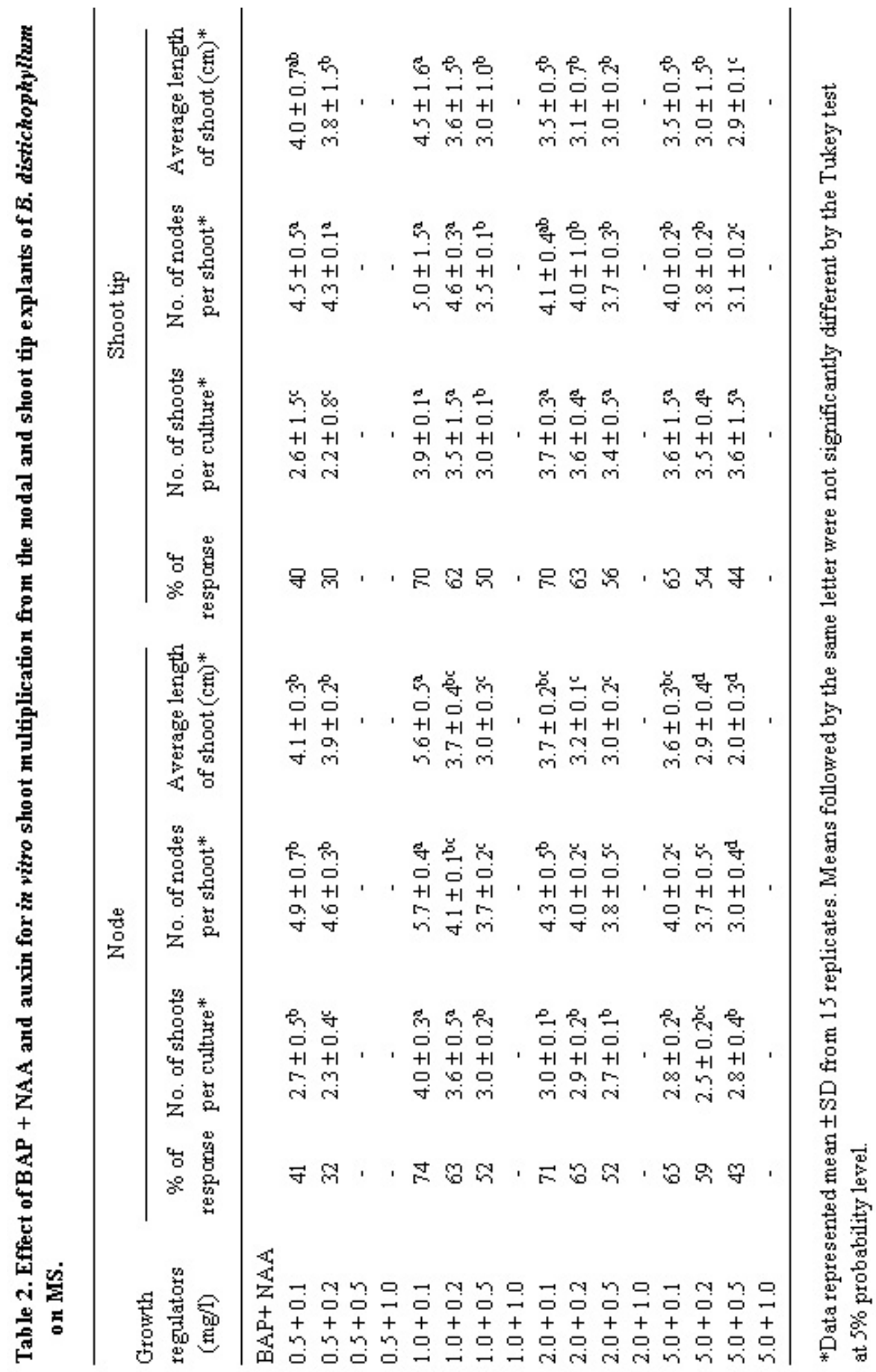




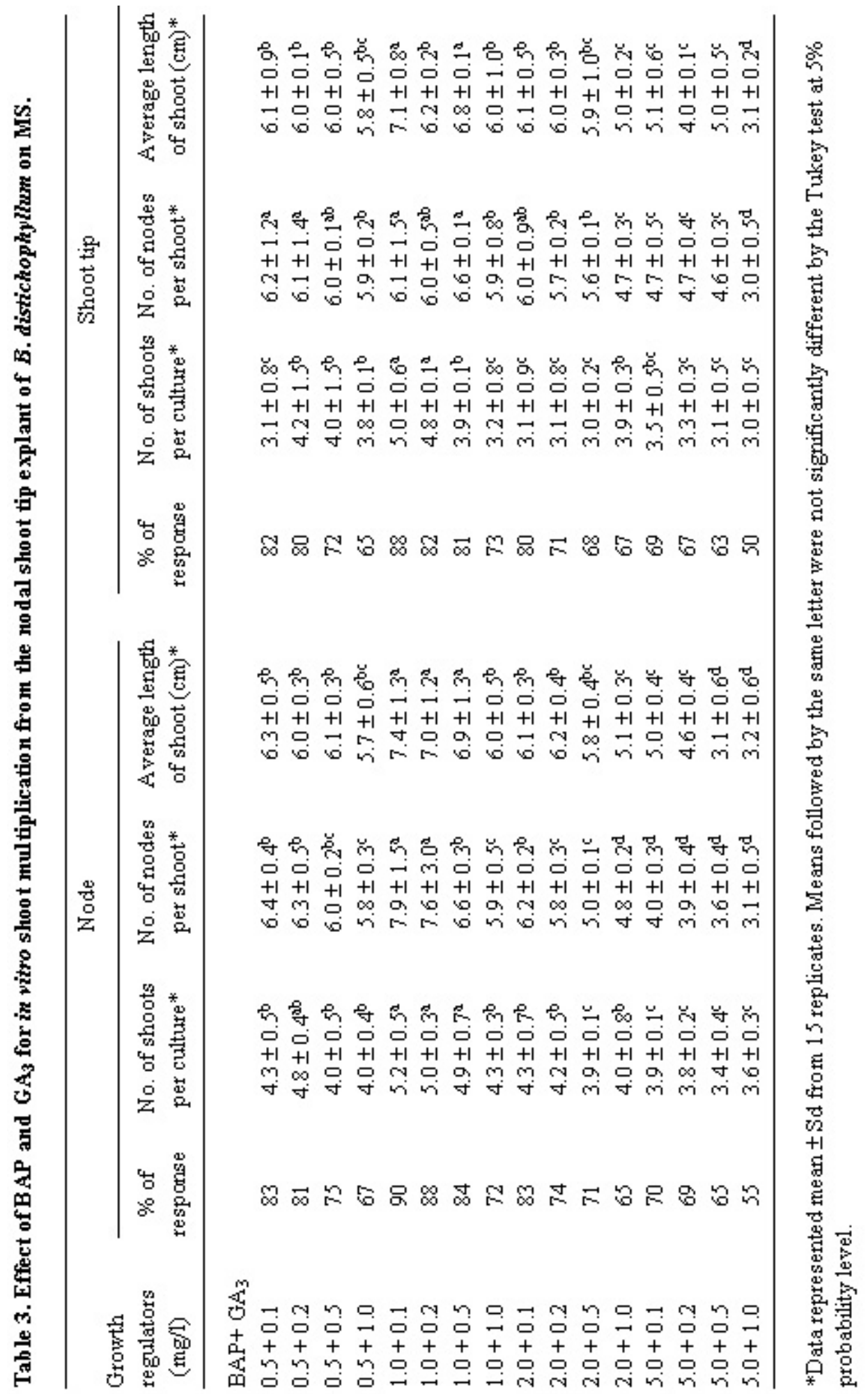


grown shoots of a particular experiment were taken and cultured on MS supplemented with various concentrations and combinations of BAP (viz., 0.5, 1.0, 2.0, $5.0 \mathrm{mg} / \mathrm{l}$ ) and $\mathrm{GA}_{3}$ (viz., $0.1,0.2,0.5,1.0 \mathrm{mg} / \mathrm{l}$ ). Results of 16 different combinations of these growth regulators are summarized in Table 3. Among different combinations on the medium supplemented with $1.0 \mathrm{mg} / 1 \mathrm{BAP}$ $+0.1 \mathrm{mg} / 1$ and $0.2 \mathrm{mg} / 1 \mathrm{GA}_{3}$ yielded the best result. After seven weeks of culture, on this combination of growth regulators, 90 and $88 \%$ explants produced $5.2 \pm 0.5$ and $5.0 \pm 0.6$ shoots per culture for both the explants, respectively in the above medium. The average length of the shoots was $7.4 \pm 1.3 \mathrm{~cm}$ (nodal explants) and $7.0 \pm 1.2 \mathrm{~cm}$ (shoot tip explants; Fig. 1d). With the increase of concentrations of BAP and $\mathrm{GA}_{3}$, the number of viable shoots, number of nodes per shoot and average shoot length decreased proportionate to the level of the added supplement.

Among different growth regulators tested for shoot multiplication, BAP gave the maximum number of shoots. $\mathrm{GA}_{3}$ affected shoot length greatly. Shoot length was reduced with an increase in the concentration levels of different cytokinins. It can be concluded from the present results that among the different treatments with cytokinins and auxins either singly or in combinations, MS with BAP was found to be more effective for shoot multiplication than other combinations.

The regenerated shoots were successfully rooted in MS supplemented with IBA $2.0 \mathrm{mg} / 1$. After sequential hardening, the plantlets were transferred to greenhouse where $71 \%$ of them survived (Fig. 1f). IBA was best for rooting of other Apiaceae members such as Ammi majus (Pande et al. 2000), Thapsia garganica (Makunga et al. 2006) and Vanasushava pedata (Karuppusamy et al. 2006). The protocol reported here uses shoot tip and nodal segments of mature explants and allows the production of up to 78 shoots per explant in three months. The regenerated plants of Bupleurum distichophyllum showed similar features that characterize field-grown plants, suggesting that this micropropagation and shoot multiplication system is suitable for conservation of germplasm of this highly prized medicinal plant

\section{References}

Fraternale D, Giamperi L, Ricci D and Rocchi MBL (2002) Micropropagation of Bupleurum fruticosum: The effect of triacontanol. Plant Cell Tiss. Org. Cult. 69: 135-140.

Hiramatsu M, Edamatsu R and Kohno M (1986) The possible involvement of free radicals in seizure mechanism. Japan. Psychiatry Neuro. 40 (3): 349-352.

Karuppusamy S, Kiranmai C, Aruan V and Pullaiah T (2006) Micropropagation of Vanasushava pedata - An endangered medicinal plant of South India. Plant Tissue Cult. \& Biotech. 16: 85-94. 
Makunga NP, Jager AK and Staden JV (2006) Improved in vitro rooting and hyperhydricity in regenerating tissues of Thapsia garganica L. Plant Cell Tiss. Org. Cult. 86: 77-86.

Motoo Y and Sawabu N (1994) Antitumor effects of saikosaponins, baicalin and baicalein on human hepatoma cell lines. Cancer Lett. 86: 91-95.

Nalawade SM, Sagare AP, Lee CY, Kao CL and Tsay HS (2003) Studies on tissue culture of Chinese medicinal plant resources in Taiwan and their sustainable utilization. Bot. Bull. Acad. Sin. 44: 79-98.

Oka H, Yamamoto S and Kuroki T (1995) Prospective study of chemoprevention of hepatocellular carcinoma with sho-saiko-to (TJ-9). Cancer 76: 743-749.

Packer M and Kliger B (1984) Bupleurum for the treatment of epilepsy. Int. J. Chin. Med. 1: 55-58.

Pande D, Srivastava PS and Rangasamy NS (2000) Xanthotoxin in tissue cultures of Ammi majus Linn. J. Trop. Med. Plants.1: 43-52.

Park KH, Park J, Koh D and Lim Y (2002) Effect of saikosaponin-A, a triterpenoid glycoside, isolated from Bupleurum falcatum on experimental allergic asthma. Phytother. Res. 16: 359-363.

Shashikala CM, Shashidhara S and Rajashekharan PE (2005) In vitro regeneration of Centella asiatica L. Plant Cell Biotech. \& Mol. Biol. 6: 53-56.

Uei-Chern C, Chi-Ni H, Mau-Shing Y, Chandra AD and Hsin-Sheng T (2006) In vitro micropropagation and ex vitro acclimatization of Bupleurum kaoi - an endangered medicinal plant native to Taiwan. In Vitro Cell Dev. Biol. - Plant. 42: 128-133.

Utrilla MP, Zarzuelo A and Risco S (1991) Isolation of a saikosaponin responsible for the antiinflammatory activity of Bupleurum gibralticum Lam. root extract. Phytother. Res. 5: 43-45.

Wakhlu AK and Sharma RK (1999) Micropropagation of Heracleum candicans Wall.: A rare medicinal herb. Soc. In Vitro Biol. 98: 1071-1074.

Yamamoto M, Kumagai A and Yamamura Y (1975) Structure and actions of saikosaponins isolated from Bupleurum falcatum L. I. Anti-inflammatory action of saikosaponins. Arzneim Forsch. 25: 1021-1023. 